\title{
Sugarcane bagasse or elephant grass hay in diets for goats: Performance, feeding behavior and carcass characteristics
}

\author{
Bagazo de caña de azúcar o heno de pasto elefante en la dieta de cabras: Rendimiento, comportamiento \\ de consumo y características de la canal
}

\begin{abstract}
Bagaço de cana de açúcar ou feno de capim elefante na dieta de caprinos: Desempenho, comportamento ingestivo e características de carcaça
\end{abstract}


José Gomes-Bezerra $^{1}$ iD; Juana C Cariri-Chagas ${ }^{2}$ iD; Emerson Moreira-Aguiar ${ }^{1}$ (D); Adriano H Nascimento-Rangel ${ }^{1}$ (D).

${ }^{1}$ Unidade Acadêmica Especializada em Ciências Agrárias, Universidade Federal do Rio Grande do Norte, Macaiba, Rio Grande do Norte, Brasil. ${ }^{2}$ Departamento de Nutrição Animal, Universidade Federal Rural do Pernambuco, Recife, Pernambuco, Brasil.
\end{abstract}

To cite this article:

Campelo-Lima VH, Antas-Urbano S, Andrade-Ferreira M, Cavalcante-Ribeiro PH, Gomes-Bezerra JI, CaririChagas JC, Moreira-Aguiar E, Nascimento-Rangel AH. Sugarcane bagasse or elephant grass hay in diets for goats: Performance, feeding behaviour and carcass characteristics. Rev Colomb Cienc Pecu 2022; 35(1): 49-59. DOI: https://doi.org/10.17533/udea.rccp.v35n1a05

\section{Abstract}

Background: Novel feeding strategies should be developed to produce high-quality meat in current goat production systems. Objective: To evaluate the effects of castration and the association of spineless cactus with sugarcane bagasse or elephant grass hay on nutrient intake, digestibility, performance, feeding behavior and carcass traits of feedlot kids. Methods: A total of 24 male kids (12 castrated and 12 intact), with an average initial weight of $18.5 \pm 3.8 \mathrm{~kg}$ were allotted to a completely randomized $2 \times 2$ factorial design (sugar cane bagasse or elephant grass hay; intact or castrated), and confined for 70 days. Results: Nutrient intake and animal performance were similar between treatments. Sugarcane bagasse increased, when compared to elephant grass hay, the digestibility of dry matter $(66.12$ vs $62.88 ; p=0.005)$, crude protein $(74.26$ vs $70.95 ; p=0.029)$ and non-fibrous carbohydrates $(91.94 \mathrm{vs} 83.07 ; \mathrm{p}<0.001)$. The forage source affected the time spent resting, ruminating and total chewing time, but there was no effect of diet on feeding and rumination efficiencies. Elephant grass hay increased, when compared to sugarcane bagasse, hot carcass weight $(9.87$ vs $10.79 ; \mathrm{p}=0.025)$ and hot carcass yield $(43.81 \mathrm{vs} 46.87 ; \mathrm{p}=0.013)$. Intact kids produced heavier hot carcasses when compared with castrated kids $(10.80$ vs $9.86 ; \mathrm{p}=0.014)$. Conclusion: Feeding intact or castrated kids with sugar cane bagasse or elephant grass hay do not affect nutrient intake and performance. Feedlot goats have improved carcass traits if kept intact and fed elephant grass hay.

Received: October 1, 2020; accepted: May 9, 2021

*Corresponding author. RN 160, Km 03, CEP 59280-000, Caixa Postal 07. E-mail: stela antas@yahoo.com.br 
Keywords: carcass yield; caprine; castration; elephant grass hay; feedlot; fiber source; goat meat; roughage; small ruminants; sugarcane bagasse.

\section{Resumen}

Antecedentes: Se requiere desarrollar nuevas estrategias de alimentación para producir carne de alta calidad en los sistemas actuales de producción de cabras. Objetivo: Evaluar el efecto de la castración y asociación de palma forrajera con bagazo de caña de azúcar o heno de pasto elefante sobre la ingesta de nutrientes, digestibilidad, rendimiento, comportamiento de alimentación y caracteristicas de la canal de cabritos de engorde. Métodos: Un total de 24 cabritos (12 castrados y 12 intactos) con peso inicial promedio de 18,5 $\pm 3,8 \mathrm{~kg}$ fueron asignados a un diseño factorial 2 × 2 completamente al azar (bagazo de caña de azucar o heno de pasto elefante; castrados o intactos) y confinados durante 70 días. Resultados: La ingesta de nutrientes y el rendimiento animal fueron similares entre tratamientos. El bagazo de caña de azúcar aumentó, en comparación con el heno de pasto elefante, la digestibilidad de la materia seca $(66,12$ vs 62,$88 ; \mathrm{p}=0,005)$, de la proteína cruda $(74,26$ vs 70,$95 ; \mathrm{p}=0,029)$ y de los carbohidratos no fibrosos (91,94 vs 83,07; $\mathrm{p}<0,001)$. La fuente de forraje afectó el tiempo de descanso, de rumia, $\mathrm{y}$ el tiempo total de masticación, pero no hubo efecto de la dieta sobre la eficiencia alimentacia y de la rumia. El heno de pasto elefante aumentó, en comparación con el bagazo, el peso de la canal caliente $(9,87$ vs 10,$79 ; \mathrm{p}=0,025)$ y el rendimiento de la canal caliente ( 43,81 vs 46,$87 ; p=0,013)$. Los animales intactos produjeron canales calientes más pesadas en comparación con los castrados $(10,80$ vs 9,86; p=0,014). Conclusión: La alimentación de cabritos enteros o castrados con bagazo de caña de azúcar o heno de pasto elefante no afecta la ingesta de nutrientes y el rendimiento. Los cabritos tienen mejores características de canal si se alimentan con heno de pasto elefante y se dejan enteros.

Palabras clave: bagazo de la caña de azúcar; carne de cabra; caprino; castración; confinamento; forraje; fuente de fibra; heno de pasto elefante; redimiento de carcasa; pequeños rumiantes.

\section{Resumo}

Antecedentes: Novas estratégias de alimentação devem ser desenvolvidas para produção de carne de qualidade nos atuais sistemas de produção de caprinos. Objetivo: Avaliar o efeito da castração e da associação da palma forrageira com o bagaço de cana de açúcar ou feno de capim elefante no consumo de nutrientes, digestibilidade, desempenho, comportamento ingestivo e características de carcaça de cabritos confinados. Métodos: Um total de 24 caprinos (12 castrados e 12 não castrados), com peso inicial médio de 18,5 $\pm 3,8 \mathrm{~kg}$, distribuídos em um delineamento experimental inteiramente casualizado, em arranjo fatorial $2 \times 2$ (bagaço de cana de açúcar ou feno de capim elefante; inteiros ou castrados), confinados durante 70 dias. Resultados: O consumo de nutrientes e o desempenho dos animais foram semelhante entre os tratamentos. $\mathrm{O}$ bagaço de cana elevou, quando comparado com o feno, a digestibilidade da matéria seca $(66,12$ vs 62,$88 ; \mathrm{p}=0,005)$, proteína $(74,26$ vs 70,$95 ; \mathrm{p}=0,029)$ e carboidratos não fibrosos $(91,94$ vs 83,$07 ; \mathrm{p}<0,001)$. As fontes de fibra afetaram os tempos de ócio, ruminação e mastigação total, mas não houve efeito para as eficiências de alimentação e ruminação. $\mathrm{O}$ feno de capim elefante aumentou, quando comparado com o bagaço, o peso de caracaça quente $(9,87$ vs 10,$79 ; \mathrm{p}=0,025)$ e o rendimento de carcaça quente $(43,81$ vs 46,$87 ; \mathrm{p}=0,013)$. Os animais inteiros produziram carcaças quentes mais pesadas em comparação aos castrados ( 10,80 vs 9,$86 ; p=0,014)$. Conclusão: Alimentar caprinos inteiros ou castrados com bagaço de cana ou feno de capim-elefante não interfere no consumo de nutrientes e desempenho. Caprinos confinados terão as características de carcaça melhoradas se mantidos intactos e alimentados com feno de capim elefante.

Palavras-chave: bagaço de cana de açúcar; carne caprina; caprino; castração; confinamento; fonte de fibra; forragem; palma forrageira; pequeno ruminante; rendimento de carcaça. 


\section{Introduction}

Goat farming stands out as an activity of cultural, social and economic relevance in the northeast region of Brazil. However, goatderived products still lack standardization. The unsatisfactory productivity rates in the region caused by the seasonality of forage production make feedlot a reasonable strategy to intensify production of high-quality meat (Urbano et al., 2015). Nutritional plans and techniques available in feedlot systems to enhance nutrient intake and animal performance allow reducing the age at slaughter and obtaining carcasses with high commercial value.

Feedlot diets are typically expensive due to the cost of concentrate feeds. However, the beneficial effects of dietary fiber cannot be neglected. Fiber maintains adequate ruminal conditions and promotes greater absorption of nutrients (Alves et al., 2016), especially when correctly associated with sources of non-fibrous carbohydrates such as spineless cactus (Ferreira et al., 2012). Correct associations between feed sources tend to enhance animal performance and, when the combination involves alternative feed sources, the beneficial effects also extend to the economics of the system.

Carcass is the most crucial element in the production chain of livestock systems focused on meat production since it contains the edible part with the highest economic value. As a result, farmers have sought increasing carcass weight under commercial conditions. According to Gois et al. (2018), carcass weight is highly dependent on growth speed, which is strongly influenced by age at slaughter and nutritional management. Therefore, diets play a key role in improving performance of young animals and production of carcasses with high yield and attractive sensory and organoleptic properties (Osório et al., 2013).

We hypothesized that different sources of fiber and sexual condition could improve the results of confined goats. Therefore, this study aimed to evaluate the effects of castration and the association of spineless cactus with elephant grass hay or sugarcane bagasse on nutrient intake, digestibility, performance, feeding behavior, and qualitative ( $\mathrm{pH}$ and temperature) and quantitative (wheights and yields) carcass traits of feedlot kids.

\section{Materials and Methods}

\section{Ethical considerations}

All procedures followed recommendations of Conselho Nacional de Controle de Experimentação Animal (CONCEA) under protocol No. 054/2017, approved by the Ethics Committee on Animal Use of Universidade Federal do Rio Grande do Norte (UFRN).

\section{Location and animals}

The experiment was carried out at the experimental station of Grupo de Estudos em Forragicultura e Produção de Ruminantes (GEFORP) - Academic Unit of Agricultural Sciences/UFRN, located in Macaíba city in the eastern mesoregion of the State of Rio Grande do Norte, Brazil.

Twenty-four mixed breed male kids, of which 12 were castrated and 12 intact, with a mean initial age of five months $(18.5 \pm 3.8 \mathrm{~kg})$ were allotted to a completely randomized $2 \mathrm{x}$ 2 factorial design with two forage sources and two sexual conditions, totaling six replicates per treatment and 24 plots. The kids were castrated with rubber rings when they were 15 days old.

The kids were confined in individual pens equiped with feeders and waterers. The animals were weighed, identified, treated for endo and ectoparasites, and vaccinated for Clostridium spp. before starting the experimental period. Then, the kids went through a 30-day period of adaptation to handling and experimental diets.

The experimental diets were formulated to be isonitrogenous and contained the same proportion of NDF in order to meet maintenance requirements of $18 \mathrm{~kg}$ kids gaining $120 \mathrm{~g}$ day-1., as set by the National Research Council (2007). 
The concentrate was composed of ground corn, soybean meal, mineral mix, sodium chloride and urea. The forage source was spineless cactus chopped in a stationary forage chopper, associated with sugarcane bagasse (SB) or elephant grass hay (EGH) (Table 1). To obtain elephant grass hay, the green material was cut (180 days after planting), then the forage was chopped in a stationary forage and exposed to the sun, on a clean surface, for the haying process. When the hay point was reached, the hay was packed in nylon bags and stored in a ventilated and moisture-free environment. The stationary forage produced particles of hay, sugarcane bagasse and spineless cactus with a size of $1.5 \mathrm{~cm}^{2}$.

Feeding was carried out twice a day ( 7 am and $3 \mathrm{pm}$ ) as total mixed ration, ad libitum, allowing for refusals of $5-10 \%$ of offered feed (DM basis). Refused feed was collected and weighed daily to adjust the feed offered and calculate dry matter intake.

Forage, concentrate ingredients, refusals and feces were sampled weekly for further analysis, which was carried out at the Laboratory of Animal Nutrition at UFRN. The analyses of dry matter (DM; method 934.01), ash (method 930.05), crude protein (CP; method 968.06), and ether extract (EE; method 920.39) were carried out according to the Association of Official Analytical Chemists (AOAC, 2012). NDF was determined using heat-stable alpha-amylase according to the methodology described by Mertens (2002). Total carbohydrates (TC) were calculated using the equation proposed by Sniffen et al. (1992), and the contents of nonfibrous carbohydrates (NFC) were calculated according to Mertens (1997).

Table 1. Ingredients and chemical composition of experimental diets.

\begin{tabular}{|c|c|c|}
\hline \multirow{2}{*}{ Ingredient (g/kg DM) } & \multicolumn{2}{|c|}{ Diets } \\
\hline & Spineless cactus $+\mathrm{SB}^{3}$ & Spineless cactus + EGH \\
\hline Spineless cactus & 300 & 250 \\
\hline Sugarcane bagasse & 296.3 & 0 \\
\hline Elephant grass hay & 0 & 350 \\
\hline Soybean meal & 180 & 180 \\
\hline Ground corn & 200 & 200 \\
\hline Sodium chloride & 5 & 5 \\
\hline Mineral Mix & 10 & 10 \\
\hline Urea & 8.7 & 5 \\
\hline Dry matter $(\mathrm{DM}, \%)^{1}$ & 200.5 & 230.2 \\
\hline Organic Matter $(\mathrm{OM})$ & 914.2 & 921.3 \\
\hline Crude Protein $(\mathrm{CP})$ & 139.7 & 133.9 \\
\hline Ether Extract (EE) & 21.8 & 20.7 \\
\hline Ash & 77.1 & 73.7 \\
\hline Neutral Detergent Fiber (NDF) & 398.1 & 394.6 \\
\hline Acid Detergent Fiber (ADF) & 335.5 & 332.1 \\
\hline Total Carbohydrates (TC) & 772.6 & 774.9 \\
\hline Non-fibrous carbohydrates (NFC) & 368.9 & 374.9 \\
\hline Lignin (LIG) & 69.4 & 72.4 \\
\hline Total digestible nutrientes $(\mathrm{TDN})^{2}$ & 76.01 & 68.5 \\
\hline
\end{tabular}


Total digestible nutrients (TDN) were estimated by a digestibility test carried out 48 days after beginning the experiment. Feces were collected directly from the rectum of animals once a day for five days, at different times (6 am, $8 \mathrm{am}, 10 \mathrm{am}, 12 \mathrm{pm}$ and $2 \mathrm{pm})$. An internal marker (iNDF - indigestible neutral detergent fiber) was used to estimate fecal output (FO) on DM basis. Samples of leftovers, feed, and feces were placed in non-woven fabric bags and incubated in the rumen of cannulated sheep for 288 hours (Valente et al., 2015). The remaining incubation material was submitted to neutral detergent extraction for iNDF determination. The FO was calculated as follows: $\mathrm{FO}=$ ([marker consumed]/[marker in feces]). Dietary TDN was estimated using the equation of Weiss (1999). Chemical composition of the diets is shown in Table 1.

Feeding behavior analysis was performed on the 40th experimental day to assess times spent feeding, ruminating, resting, and total chewing time. Instant scan sampling was used to evaluate feeding behavior for 48 hours at 10-min intervals (Johnson and Combs, 1991). Feeding time (FT, $\mathrm{h}$ /day), and total chewing time (TCT, h/day) were evaluated following the methodology of Bürger et al. (2000).

The kids were weighed every 14 days after solid fasting for 16 hours. Total weight gain (TWG) was obtained by the difference between final weight (FW) and initial weight, while average daily gain (ADG) was obtained by the ratio of TWG over the number of days in feedlot until slaughter, not including the adaptation period: $\mathrm{ADG}=(\mathrm{WG} / 70)$. After 70 days in feedlot, in addition to the 30 of adaptation, the kids were individually weighed to obtain final weight (FW) after solid fasting of 16 hours. At slaughtering, the animals were stunned by concussion to cause unconsciousness and then bled with bilateral severance of the carotid arteries and jugular veins.
At the end of skinning and evisceration, the head and legs were removed for determination of hot carcass weight (HCW), which was then used to calculate hot carcass yield $[\mathrm{HCY}(\%)=\mathrm{HCW} /$ FW $\times 100]$. Full and empty gastrointestinal tract (GIT), urinary bladder and gallbladder were weighed to determine empty body weight $(\mathrm{EBW})$ and biological yield $[\mathrm{BY}(\%)=\mathrm{HCW} /$ $\mathrm{EBW} \times 100]$.

The $\mathrm{pH}$ and carcass temperature were measured at 0 and 24 hours postmortem in the semimembranosus muscle using a $\mathrm{pH}$ meter equipped with glass electrode and a temperature probe (Testo $\AA$, model 205). Carcasses were placed in a cold chamber $\left( \pm 4{ }^{\circ} \mathrm{C} ; 24\right.$ hours $)$ and the chilled carcasses were weighed to obtain cold carcass weight $(\mathrm{CCW})$.

The data were analyzed using the PROC GLM of SAS (version 9.4, SAS Institute Inc., Cary, NC, USA, 2013) after testing for residual normality and homogeneity of variance. Given the high probability of Type II error, a significance level of $\alpha=0.05$ was used. When necessary, the means were compared by the F-test. The initial body weight was included as a covariate, as follows:

$Y i j k=\mu+F i+S j+\left(F^{*} S\right) i j \beta(X i j k-X)+$ eijk, where:

Yijk $=$ Observed value of the dependent variable;

$\mu=$ Overall mean;

$\mathrm{Fi}=$ Effect of forage source;

$\mathrm{Sj}=$ Effect of sexual condition;

$\left(F^{*} \mathrm{~S}\right) \mathrm{ij}=$ Effect of interaction (forage source $\mathrm{x}$ sexual condition);

$\beta(\mathrm{Xijk}-\mathrm{X})=$ Effect of the covariate (initial body weight);

eijk $=$ Experimental error. 


\section{Results}

Fiber sources and sexual conditions did not affect $(\mathrm{p}>0.05)$ nutrient intake $(\mathrm{kg} /$ day $)$ : dry matter intake (DMI), crude protein (CPI), neutral detergent fiber (NDFI) and non-fibrous carbohydrates (NFCI) (Table 2).

The fiber source influenced $(\mathrm{p}<0.05)$ feeding behavior. The TSR was higher for animals fed SB, whereas the TSRU and TCT were higher for animals fed elephant grass hay (Table 3).

Final weight (FW), average daily gain (ADG), total gain (TG) and empty body weight
(EBW), as well as qualitative carcass traits (pH and temperature at 0 and 24 hours post mortem) were not affected by diet, sexual condition, or their interaction $(p>0.05)$ (Table 4). Hot carcass weight $(\mathrm{HCW})$ and cold carcass weight $(\mathrm{CCW})$ were affected $(p<0.05)$ by sexual condition and fiber source, and were higher for intact animals, animals fed elephant grass hay (Table 4), respectively. There was a significant effect of diet ( $\mathrm{p}<0.05$ ) on hot carcass yield (HCY) and biological yield (BY), with better results for animals fed elephant grass hay (Table 4).

Table 2. Dry matter intake, nutrient intake and coefficients of digestibility of diets for kids fed sugarcane bagasse and elephant grass hay as forage source.

\begin{tabular}{|c|c|c|c|c|c|c|c|c|}
\hline \multirow{2}{*}{ Items } & \multicolumn{2}{|c|}{ Diets } & \multicolumn{2}{|c|}{ Sexual condition } & \multirow{2}{*}{$\frac{\mathrm{CV}}{\mathrm{( \% )}}$} & \multicolumn{3}{|c|}{ P-value } \\
\hline & $\mathrm{SB}^{10}$ & EGH $^{11}$ & INT $^{12}$ & $\mathrm{CAST}^{13}$ & & $\mathrm{D}^{14}$ & $\mathrm{SC}^{15}$ & $\mathrm{D} \times \mathrm{SC}$ \\
\hline DMI (kg/day) $)^{1}$ & 0.567 & 0.670 & 0.663 & 0.573 & 18.51 & 0.071 & 0.088 & 0.063 \\
\hline CPI $(\mathrm{kg} / \text { day })^{2}$ & 0.078 & 0.088 & 0.089 & 0.077 & 19.19 & 0.189 & 0.083 & 0.071 \\
\hline NDFI (kg/day $)^{3}$ & 0.219 & 0.258 & 0.256 & 0.222 & 18.68 & 0.074 & 0.083 & 0.065 \\
\hline NFCI (kg/day) ${ }^{4}$ & 0.209 & 0.247 & 0.245 & 0.211 & 18.02 & 0.059 & 0.071 & 0.060 \\
\hline $\operatorname{DMD}(\%)^{5}$ & 66.12 & 62.88 & 64.51 & 64.49 & 3.23 & 0.005 & 0.966 & 0.795 \\
\hline CPD $(\%)^{6}$ & 74.26 & 70.95 & 72.50 & 72.71 & 4.16 & 0.029 & 0.818 & 0.410 \\
\hline NDFD $(\%)^{7}$ & 41.00 & 40.04 & 40.83 & 40.21 & 11.36 & 0.608 & 0.815 & 0.608 \\
\hline $\operatorname{NFCD}(\%)^{8}$ & 91.94 & 83.07 & 86.58 & 88.43 & 3.12 & $<0.001$ & 0.160 & 0.825 \\
\hline TDNI (kg/day) ${ }^{9}$ & 0.431 & 0.459 & 0.471 & 0.412 & 16.91 & 0.364 & 0.104 & 0.065 \\
\hline
\end{tabular}

${ }^{1}$ Dry matter intake, ${ }^{2}$ Crude protein intake, ${ }^{3}$ Neutral detergent fiber intake, ${ }^{4}$ Non-fibrous carbohydrates intake, ${ }^{5}$ Dry matter digestibility, ${ }^{6}$ Crude protein digestibility, ${ }^{7}$ Neutral detergent fiber digestibility, ${ }^{8}$ Non-fibrous carbohydrates digestibility, ${ }^{9}$ Total digestible nutrients intake, ${ }^{10}$ Sugarcane bagasse, ${ }^{11}$ Elephant grass hay, ${ }^{12}$ Intact, ${ }^{13}$ Castrated, ${ }^{14}$ Diet, ${ }^{15}$ Sexual condition.

Table 3. Feeding behavior of kids fed sugarcane bagasse and elephant grass hay as forage source.

\begin{tabular}{|c|c|c|c|c|c|c|c|c|}
\hline \multirow{2}{*}{ Items } & \multicolumn{2}{|c|}{ Diets } & \multicolumn{2}{|c|}{ Sexual condition } & \multirow{2}{*}{$\begin{array}{l}\mathrm{CV} \\
(\%)\end{array}$} & \multicolumn{3}{|c|}{ P-value } \\
\hline & $\mathrm{SB}^{5}$ & EGH $^{6}$ & INT $^{7}$ & CAST $^{8}$ & & $\mathrm{D}^{9}$ & $\mathrm{SC}^{10}$ & D X SC \\
\hline $\mathrm{TSR}(\min )^{1}$ & 1812.20 & 1539.00 & 1651.71 & 1699.50 & 11.16 & 0.006 & 0.499 & 0.167 \\
\hline $\operatorname{TSRU}(\min )^{2}$ & 865.62 & 1100.58 & 999.44 & 966.45 & 17.25 & 0.008 & 0.573 & 0.130 \\
\hline $\mathrm{FT}(\min )^{3}$ & 202.17 & 240.43 & 228.84 & 213.76 & 20.14 & 0.099 & 0.480 & 0.991 \\
\hline $\mathrm{TCT}(\min )^{4}$ & 1067.80 & 1341.00 & 1228.29 & 1180.51 & 15.53 & 0.006 & 0.498 & 0.167 \\
\hline
\end{tabular}

${ }^{1}$ Time spent resting, ${ }^{2}$ Time spent ruminating, ${ }^{3}$ Feeding time, ${ }^{4}$ Total chewing time (FT + TSRU), ${ }^{5}$ Sugarcane bagasse, ${ }^{6}$ Elephant grass hay, ${ }^{7}$ Intact, ${ }^{8}$ Castrated, ${ }^{9}$ Diet, ${ }^{10}$ Sexual condition. 
Table 4. Performance of goats fed sugarcane bagasse or elephante grass hay as forage source.

\begin{tabular}{|c|c|c|c|c|c|c|c|c|}
\hline \multirow{2}{*}{ Items } & \multicolumn{2}{|c|}{ Diets } & \multicolumn{2}{|c|}{ Sexual condition } & \multirow{2}{*}{$\begin{array}{c}\text { CV } \\
(\%)\end{array}$} & \multicolumn{3}{|c|}{ P-value } \\
\hline & $\mathrm{SB}^{10}$ & EGH $^{11}$ & INT $^{12}$ & $\mathrm{CAST}^{13}$ & & $D^{14}$ & $\mathrm{SC}^{15}$ & D X SC \\
\hline $\mathrm{FW}(\mathrm{kg}) 1$ & 22.40 & 22.95 & 23.46 & 21.89 & 8.84 & 0.529 & 0.079 & 0.062 \\
\hline ADG (kg/day)2 & 0.055 & 0.071 & 0.072 & 0.055 & 38.70 & 0.173 & 0.125 & 0.117 \\
\hline TWG (kg/day)3 & 3.89 & 4.92 & 5.03 & 3.78 & 39.18 & 0.211 & 0.104 & 0.097 \\
\hline $\mathrm{HCW}(\mathrm{kg}) 4$ & 9.87 & 10.79 & 10.80 & 9.86 & 7.70 & 0.025 & 0.014 & 0.057 \\
\hline $\mathrm{CCW}(\mathrm{kg}) 5$ & 9.69 & 10.52 & 10.56 & 9.64 & 8.55 & 0.050 & 0.023 & 0.067 \\
\hline EBW (kg)6 & 17.91 & 16.70 & 18.45 & 16.16 & 22.87 & 0.581 & 0.171 & 0.073 \\
\hline HCY (\%)7 & 43.81 & 46.87 & 45.69 & 44.99 & 5.16 & 0.015 & 0.515 & 0.767 \\
\hline BY (\%)8 & 55.32 & 59.76 & 57.84 & 57.23 & 6.00 & 0.020 & 0.781 & 0.357 \\
\hline $\mathrm{pHOh}$ & 6.84 & 6.79 & 6.86 & 6.77 & 2.58 & 0.463 & 0.306 & 0.789 \\
\hline $\mathrm{pH} 24 \mathrm{~h}$ & 5.67 & 5.62 & 5.67 & 5.62 & 1.64 & 0.163 & 0.380 & 0.351 \\
\hline T9 0h $\left({ }^{\circ} \mathrm{C}\right)$ & 34.98 & 34.03 & 33.84 & 35.17 & 4.35 & 0.184 & 0.056 & 0.052 \\
\hline T $24 \mathrm{~h}\left({ }^{\circ} \mathrm{C}\right)$ & 6.77 & 6.73 & 6.89 & 6.61 & 9.20 & 0.823 & 0.351 & 0.999 \\
\hline
\end{tabular}

${ }^{1}$ Final weight, ${ }^{2}$ Average daily gain, ${ }^{3}$ Total weight gain, ${ }^{4}$ Hot carcass weight, ${ }^{5}$ Cold carcass weight, ${ }^{6}$ Empty body weight, ${ }^{7}$ Hot carcass yield, ${ }^{8}$ Biological yield, ${ }^{9}$ Temperature, ${ }^{10}$ Sugarcane bagasse, ${ }^{11}$ Elephant grass hay, ${ }^{12}$ Intact, ${ }^{13}$ Castrated, ${ }^{14}$ Diet; ${ }^{15}$ Sexual condition.

\section{Discussion}

The DMI was lower than that recommended by the NRC (2007) for kids (820 g/day), which may be related to the feeding habit of goats. Despite being versatile, goats are classified as intermediate feeders (Hoffmann, 1989) and require longer periods for adaptation to new conditions, especially when removed from the Caatinga environment and allocated in individual pens with totally different diets, not only in terms of feed offered but also in terms of composition and assimilation. Garcez et al. (2020) report that even in feedlot systems, goats express selectivity and spend most of the time searching and selecting food, which influences both quality and quantity of the feed consumed besides chemical composition of leftovers causing variation in nutrient intake. Therefore, the typical feeding habit of goats not adapted to feedlot systems seems to have a greater influence on DMI than fiber source and sexual condition. Moreover, moisture content of diets, which contained 25 and $30 \%$ of spineless cactus, also contributed to the low DMI. Goats prefer less moist and more nutrient-rich feedstuffs, such as grasses, shrub and tree plants, due to their intrinsic selective capacity (Costa et al., 2015; Pinho et al., 2019).
The study of Lima Júnior et al. (2015) corroborates our argument when they calculated DMI of feedlot goats fed diets containing 30\% spineless cactus associated with Tifton 85 hay (415 g DM/day) and cassava hay (544 g DM/ day), reporting values lower than those obtained in the present study (567 and $670 \mathrm{~g} \mathrm{DM}$ /day for $\mathrm{BS}$ and $\mathrm{EGH}$, respectively).

The literature reports that DMI in ruminants can be physically limited by rumen filling, which is regulated by the proportion of total dietary NDF (Mertens, 1997, Alves et al., 2016). Goats, in turn, have a high intake capacity of forages with high NDF content (Formiga et al., 2020). When assessing fiber levels for goats, Branco et al. (2011) indicated a limitation in DMI from $35 \%$ of NDF in the diet, lower than the present study. However, diets had comparable NDF levels $(40 \%)$, which led to similar NDF and DMI. The lack of effect of treatments on DM led to similar intakes of CP, NFC and TDN.

According to Pessoa et al. (2013), the carbohydrates present in the spineless cactus have high degradation rates, which may favor diet digestibility. An increase in dietary NFC concentration changes the microbial environment in the gastrointestinal tract of goats 
by increasing the amount of energy available in the rumen for bacterial growth (Ma et al., 2014; Ma et al., 2015; Pinho et al., 2019). This can increase nutrient digestibility. Thus, a greater inclusion of spineless cactus in sugarcane bagasse-based diets increased the digestibility of DM, CP and NFC in this treatment.

Muniz et al. (2012) evaluated the ruminal kinetics of the fibrous fraction of roughages, finding that an increase of approximately 3\% lignin content in the feed, as found in the present study, decreases nutrient digestibility, justifying the lower values for EGH. Lignin is considered a limiting factor for fiber degradation due to its barrier effect that prevents microbial adhesion and colonization (Cabral et al., 2020).

The high digestibility of sugarcane bagassebased diets reduced rumination and increased TSR since both DMI and NDFI, which could influencethis characteristic, were similarbetween treatments. However, the low digestibility of elephant grass-based diets increased TSRU and, consequently, TCT, although feeding times were similar between diets.

In addition to the NDF level, fiber composition can influence behavioral activities, especially rumination due to physical barriers to the digestive action of microorganisms (Azevedo et al., 2013; Ramos et al., 2016). Thus, diets with similar NDF levels but composed of different feeds can predispose animals to different expenditures in daily activities (Carvalho et al., 2011).

Similarity of DMI and nutrient intake between treatments resulted in similar animal performance. Feed intake affects animal performance, since the ingested nutrients are converted into animal products (Pompeu et al., 2012).

Daily and total weight gain of kids were lower than the average $120 \mathrm{~g}$ /day expected by the NRC (2007). It is relevant to highlight that DMI did not reach the expected target $(820 \mathrm{~g} /$ day), which would explain the low weight gain.

Regarding sex, it directly influences animal physiology. According to Pellegrini et al.
(2012), intact males have higher growth speed than castrated males due to the anabolic effects of testosterone (Paim et al., 2011). It explains the higher results for $\mathrm{HCW}$ and $\mathrm{CCW}$ in intact animals (10.8 and $10.56 \mathrm{~kg}$ ) in relation to castrated kids (9.86 and $9.64 \mathrm{~kg}$ ). Both HCW and $\mathrm{CCW}$ are direct measures of body tissue composition (muscle, bone and fat).

Castration increases fat deposition in the carcass (Gois et al., 2018). In goats, fat deposition occurs primarily in the form of visceral fat, which is lost during evisceration (Rodrigues et al., 2013). Thus, it does not significantly influence the final carcass weight and yield.

The HCW and CCW results, although the highest for kids fed elephant grass hay, were similar to the findings of Lima Junior et al. (2015) for HCW (10.22 and $9.45 \mathrm{~kg}$ ) and CCW (9.57 and $8.85 \mathrm{~kg}$ ) for goats fed Tifton 85 hay and cassava hay associated with spineless cactus, respectively. This indicates that sugarcane bagasse and elephant grass hay are good alternatives to Tifton hay. The increase in hot carcass yield (HCY) and biological yield (BY) are in line with the increase in carcass weight. In a study with feedlot goats, Salles et al, (2013) reported lower BYs (50.95\%) than those obtained in the present study for both forage sources $(55,32$ and $59,76 \%$ for SB and $\mathrm{EGH}$, respectively). Biological yield was influenced by fiber source, most likely because when considering the empty body weight, this parameter is affected by variations in the gastrointestinal tract contents (Bezerra et al., 2017), which depends on diet intake.

The $\mathrm{pH}$ at 24 hours postmortem averaged 5.6, which is within the recommended range of 5.55.8 for carcasses of small ruminants after cooling (Della Malva et al., 2016). Therefore, it is possible that pre-slaughter handling procedures were carried out without animal stress. The temperature at 24 hours postmortem was high, possibly due to the cold chamber setup.

In conclusion, feeding intact or castrated kids with sugar cane bagasse or elephant grass hay 
does not affect nutrient intake and performance. However, feedlot goats fed elephant grass hay improve carcass traits if kept intact, which is our recommend combination of strategies.

\section{Declarations}

\section{Acknowledgements}

Appreciation is expressed to Marcelo de Andrade Ferreira for assistance in diet preparation for the experiments.

\section{Funding}

This research was supported by Universidade Federal do Rio Grande do Norte, Unidade Acadêmica Especializada em Ciências Agrárias.

\section{Conflicts of interest}

The authors declare they have no conflicts of interest with regard to the work presented in this report.

\section{Author contributions}

VH Campelo-Lima, PH Cavalcante-Ribeiro, JI Gomes-Bezerra were responsible for data collection. S Antas-Urbano, M Andrade-Ferreira coordinated the research. E Moreira-Aguiar, AH Nascimento-Rangel assisted in laboratory analysis. JC Cariri-Chagas analyzed the data.

\section{References}

Alves AR, Pascoal LAF, Cambuí GB, Trajano JS, Silva CM, Gois GC. Fibra para ruminantes: Aspecto nutricional, metodológico e funcional. Pubvet 2016; 10(7):513-579.

AOAC, V. AOAC INTERNATIONAL. AOAC Official Methods of Analysis, 2012.

Azevedo RA, Rufino LMA, Santos ACR, Ribeiro Junior CS, Rodriguez NM, Gerassev LC. Comportamento ingestivo de cordeiros alimentado com torta de macaúba. Arq Bras Med Vet Zootec 2013; 65(2):490-496. DOI: https://doi.org/10.1590/S0102-09352013000200027
Bezerra AB, Gonzaga Neto S, Medeiros NA, Carvalho FFR, Bispo SV, Souza AP, Santos Neto JM, Ribeiro LPS. Carcass characteristics of Canindé goats subjected to feed restriction. Cienc Rural 2017; 47(8):e20160690. DOI: https://dx.doi.org/10.1590/0103-8478cr20160690

Branco RH, Rodrigues MT, Silva MMC, Rodrigues CAF, Queiroz AC, Araujo FL. Desempenho de cabras em lactação alimentadas com dietas com diferentes níveis de fibra oriundas de forragem com maturidade avançada. R Bras Zootec 2011; 40(5):1061-1071. DOI: https://doi.org/10.1590/S1516-35982011000500018

Bürger PJ, Pereira JC, Queiroz AC, Silva JFC, Valadares Filho SC, Cecon PR, Casali ADP. Comportamento ingestivo em bezerros holandeses alimentados com dietas contendo diferentes níveis de concentrado. R Bras Zootec 2000; 29(1):236-242. DOI: http://dx.doi.org/10.1590/S1516-35982000000100031

Cabral AMD, Carvalho FFR, Santos GCL, Ferreira GC, Silva MJMS, Santos GRA, Belo Junior GS, Melo ND. Use of sugar cane to feed lactating dairy goats. Arq Bras Med Vet Zootec 2020; 72(6):2297-2307. DOI: https://doi.org/10.1590/1678-4162-12022

Carvalho GGP, Garcia R, Pires AJV, Detmann E, Ribeiro LSO, Chagas DMT, Silva RR, Pinho BD. Comportamento ingestivo em caprinos alimentados com dietas contendo cana-de-açúcar tratada com óxido de cálcio. R Bras Zootec 2011; 40(8):1767-1773. DOI: https://doi.org/10.1590/S1516-35982011000800021

Costa JV, Oliveira ME, Moura RMAS, Costa Júnior MJN, Rodrigues MM. Comportamento em pastejo e ingestivo de caprinos em sistema silvipastoril. R Ciênc Agron 2015; 46(4):865-872. DOI: https://doi.org/10.5935/1806-6690.20150075

Della Malva A, Albenizio M, Annicchiarico G, Caropese M, Muscio A, Santillo A, Marino RO. Relationship between slaughtering age, nutritional and organoleptic properties of Altamurana lamb meat. Small Ruminant Res 2016; 135:39-45. DOI: https://doi.org/10.1016/j.smallrumres.2015.12.020 
Ferreira MA, Bispo SV, Rocha Filho RR, Urbano SA, Costa CTF. The use of cactus as forage for dairy cows in semi-arid regions of Brazil. Organic farming and food production, 2012; 169p. DOI: http://dx.doi.org/10.5772/53294

Formiga LDAS, Paulo PFM, Cassuce MR, Andrade AP, Silva DS, Saraiva EP. Ingestive behavior and feeding preference of goats reared in degraded caatinga. Ciênc anim bras 2020; 21 :e-52435. DOI: http://dx.doi.org/10.1590/1809-6891v21e-52435

Garcez BS, Alves AA, Oliveira ME, Moreira Filho MA, Azevedo DMMR, Lacerda MSB. Nutrient metabolism and ingestive behavior of goats fed diets containing palm tree fruit. Rev Cienc Agron 2020; 51(2):e20196608. DOI: https://doi.org/10.5935/1806-6690.20200034

Gois GC, Campos FS, Pessoa RMS, Silva AAF, Ferreira JMS, AGS Matias AGS, Nogueira GHMSMF, Santos RN. Qualidade da carne de ovinos de diferentes pesos e condição sexual. Pubvet 2018; 12(5):172-178. DOI: https://doi.org/10.22256/pubvet.v12n5a97.1-9

Hoffmann RR. Evolutionary steps of ecophysiological adaptation and diversification of ruminants: a comparative view of their digestive system. Oecologia 1989; 78:443-457.

Johnson TR, Combs DK. Effects of prepartum diet, inert rumen bulk, and dietary polyethylene glycol on dry matter intake of lactating dairy cows. J Dairy Sci 1991; 74(3):933-944. DOI: https://doi.org/10.3168/jds.S0022-0302(91)78243-X

Lima Junior DM, Carvalho FFR, Ferreira BF, Batista AMV, Ribeiro MN, Monteiro PDB, Monteiro S. Maniçoba hay feeding Moxoto goats. Semin Ciênc Agrár 2015; 36(3) 2211-2221. DOI: http://doi.org./10.5433/1679$\underline{0359.2015 v 36 n 3 S u p l 1 p 2211}$

Ma T, Deng KD, Tu Y, Jiang CG, Zhang NF, Li YL, Si BW, Lou C, Diao QY. Effect of dietary concentrate: forage ratios and undegraded dietary protein on nitrogen balance and urinary excretion of purine derivatives in dorper thin-tailed han crossbred lambs. Asian-
Australas J Anim Sci 2014;27:161-168. DOI: https://doi.org/10.5713/ajas.2013.13338

Ma T, Tu Y, Zhang NF, Deng KD, Diao QY. Effect of the ratio of non-fibrous carbohydrates to neutral detergent fiber and protein structure on intake, digestibility, rumen fermentation, and nitrogen metabolism in lambs. Asian Australas J Anim Sci 2015; 28:1419-1426. DOI: https://doi.org/10.5713/ajas.15.0025

Mertens DR. Creating a system for meeting the fiber requirements of dairy cows. Int J Dairy Sci 1997; 80(7): 1463-1481. DOI: https://doi.org/10.3168/jds. $\underline{\mathrm{S} 0022-0302(97) 76075-2}$

Mertens DR. Gravimetric determination of amylase treated neutral detergent fiber in feeds with refluxing in beaker or crucibles: collaborative study. J AOAC Int 2002; 85(6):1217-1240.

Muniz EB, Mizubuti IY, Pereira ES, Pimentel PG, RibeiroELDA,PintoAP. Cinética ruminal da fração fibrosa de volumosos para ruminantes. Revista Ciência Agronômica 2012; 43(3), 604-610. DOI: https://doi.org/10.1590/S1806-66902012000300025

National Reseach Council. Nutrient requirements of small ruminants. Washington, DC: National Academy Press. 2007; 362p.

Osorio MTM, Bonacina MS, Osorio JCS, Rota EL, Ferreira OGL, Treptow RO, Gonçalves MS, Oliveira MM. Características sensoriais da carne de ovinos Corriedale em função da idade de abate e da castração. Agrarian 2013; 6(19):60-66.

Paim TDP, Cardoso MTM, Borges BO, Gomes EF, Louvandini H, McManus C. Estudo econômico da produção de cordeiros cruzados confinados abatidos em diferentes pesos. Ciênc Anim Bras 2011; 12(1):48-57. DOI: http://doi.org/10.5216/cab.v12i1.5894

Pellegrini LG, Pellegrini CRS, Monteiro ALG, Neumann M. Efeito do sexo no desempenho de cordeiros desmamados terminados em pasto de Azevém. Synergismus scyentifica UTFPR, 2012; 7(1):10-15. 
Pessoa RAS, Ferreira MA, Silva FMD, Bispo SV, Wanderley WL, Vasconcelos PC. Diferentes suplementos associados à palma forrageira em dietas para ovinos: consumo, digestibilidade aparente e parâmetros ruminais. Rev Bra Saúde Prod Anim 2013; 14(3):508-517. DOI: https://doi.org/10.1590/S1519-99402013000300012

Pinho RMA, Santos EM, de Oliveira JS, de Carvalho GGP, Alves JP, Macêdo AJdaS, Pereira GA, Pereira DM, Perazzo AF, Zanine AdeM. Relationship between forage neutral detergent fiber and non-fibrous carbohydrates on ruminal fermentation products and neutral detergent fiber digestibility in goats. Rev Colomb Cienc Pecu 2019; 32(2):126-138. DOI: https://doi.org/10.17533/udea.rccp.v32n2a06

Pompeu RCFF, Cândido MJD, Pereira ES, Bomfim MAD, Carneiro MSDS, Rogério MCP, Sombra WA, Lopes MN. Desempenho produtivo e característicasdecarcaçadeovinosemconfinamento alimentados com rações contendo torta de mamona destoxificada em substituição ao farelo de soja. R Bras Zootec 2012; 41(3):726-733. DOI: http://dx.doi.org/10.1590/S1516-35982012000300036

Ramos AFO, Pinho BD, Junior L, Silva AGM, Faturi C, Martorano LG, Manno MC, Souza LKR, Sousa LF. Ingestive behavior of sheep fed Brazil nut cake in the diet Comportamento ingestivo de ovinos alimentados com torta de castanha-do-pará na dieta. Semina: Ciências Agrárias 2016; 37(4):2259-2268. DOI: https://doi.org/10.5433/1679-0359.2016v37n4p2259

Rodrigues L, Gonçalves HC, Medeiros BBL, Menezes JJL, Maestá AS. Avaliação da somatotropina bovina recombinante (rbST) nos não-componentes da carcaça de cabritos de três genótipos. Ci Anim Bras 2013; 14(2):143-150. DOI: https://doi.org/10.5216/cab.v14i2.8984

Salles FM, Zambom MA, Alcalde CR, Macedo FAF, Souza R, Gomes LC, Dias FB, Molina BSL. Carcass characteristics of goat kids in two finishing systems. Arq Bras Med Vet Zootec 2013; 65(6):1867-1875. DOI: http://dx.doi.org/10.1590/S0102-09352013000600039

SAS $^{\circledR}$, Statistical Analisys System. SAS/STAT User's Guide. Versão 9.4. Cary, NC, USA: SAS Institute Inc; 2013.

Sniffen CJ, O'Connor JD, Van Soest PJ, Fox DG, RusselJB.Anet carbohydrateand protein system for evaluating cattle diets: II. Carbohydrate and protein availability. J Anim Sci 1992; 70(11):3562-3577. DOI: https://doi.org/10.2527/1992.70113562x

Urbano SA, Ferreira MA, Veras RML,Azevedo OS, Santos Filho HB, Vasconcelos GA, Oliveira JPF. Características de carcaça e composição tecidual de ovinos Santa Inês alimentados com manipueira. Rev Bras Ciênc Agrár 2015; 10(3):466-472. DOI: http://doi.org/10.5039/agraria.v10i3a4812

Valente TNP, Detmann E, Sampaio CB. Recent advances in evaluation of bags made from different textiles used in situ ruminal degradation. Can J Anim Sci 2015; 95(4): 493-498. DOI: https://doi.org/10.4141/cjas-2015-100

Weiss WP. Energy prediction equations for ruminant feeds. In: Proceedings Cornell Nutrition Conference for Feed Manufacturers. Ithaca, 1999; 176-185. 